\title{
New and poorly-known species of the subgenus Parascatonomus Paulian, 1932 (Scarabaeidae: Onthophagus) from Vietnam
}

\author{
Новый и малоизвестный виды подрода Parascatonomus \\ Paulian, 1932 (Scarabaeidae: Onthophagus) из Вьетнама
}

\author{
V.K. Zinchenko \\ B.К. Зинченко
}

Institute of Systematics and Ecology of Animals, Russian Academy of Sciences, Siberian Branch, Frunze Street 11, Novosibirsk 630091 Russia. E-mail: vscar@ngs.ru.

Институт систематики и экологии животных, Сибирское отделение РАН, ул. Фрунзе 11, Новосибирск 630091, Россия.

KEY WORDS: Onthophagus, Parascatonomus, Vietnam, new species, poorly-known species, new locality.

КЛЮЧЕВЫЕ СЛОВА: Onthophagus, Parascatonomus, Вьетнам, новый вид, неизвестная самка, новые локалитеты.

ABSTRACT: Ontophagus (Parascatonomus) abramovi sp.n. $\left(\mathrm{O}^{7}\right)$ from the Vietnamese Province Kon Tum is described and illustrated. A new distributional record and a description of the previously unknown female of $O$. (P.) rhombocephalus Kabakov, 1992 is provided.

РЕЗЮМЕ: Из Вьетнамской провинции Кон Тум описывается Ontophagus (Parascatonomus) abramovi sp.n. $\left(\sigma^{7}\right)$. Впервые даётся описание самки и указывается новый локалитет для $O$. (P.) rhombocephalus Kabakov, 1992.

\section{Introduction}

In Vietnam, the subgenus Parascatonomus Paulian, 1932 is represented by 22 species [Kabakov, 1992; Kabakov, Napolov, 1999; Tarasov, Kabakov, 2010; Tarasov, Solodovnikov, 2011, Masumoto, Ochi, 2014]. The subgenus can be reliably diagnosed by the presence of a well-developed protuberance on the metasternum. The scutellum is hidden under the elytral base. Many Parascatonomus species are not coprophagous, preferring animal corpses and/or human faeces. The aims of the present paper are: (1) to diagnose, describe and illustrate a new Parascatonomus species from Vietnam, and (2) to describe the female of Onthophagus $(P$.) rhombocephalus Kabakov, 1992 for the first time.

\section{Material and methods}

The studied material on dung beetles was collected by Alexei Abramov (Zoological Institute, St. Petersburg) from the Province of Kon Tum, Central Vietnam. Terminology of paramer parts taken from Masumoto \&
Ochi [2014] and Krikken \& Huijbregts [2008]. The material was studied and photographed by means of a Zeiss Stemi 2000-C and Altami PS0745-T binocular microscope. Information from individual data labels is separated by "/".

The holotype of the new species and the female of $O$. $(P$.) rhombocephalus are deposited in the entomological collection of the Siberian Zoological Museum of the Institute of Systematics and Ecology of Animals, Novosibirsk, Russia.

\section{Systematic part}

Onthophagus (Parascatonomus) abramovi Zinchenko sp.n.

Figs 1-6.

TYPE MATERIAL. Holotype, $\sigma^{7}$, bearing the following labels:

1. White, printed: Vietnam, Kon Tum Prov., / Kon Plong District, $14 \mathrm{~km} \mathrm{~N} /$ of Kon Plong Town, h 1030 m / 14 $43^{\prime} 20^{\prime \prime}$, $108^{\circ} 18^{\prime}$ 58' 'E / 9-23.04.2015 / A.V. Abramov leg.;

2. Red, printed: HOLOTYPUS / Onthophagus (Parascatonomus) abramovi Zinchenko 2018.

DESCRIPTION. Male. Body black. Antennal clubs and mouth parts yellowish brown. Total body length $8.2 \mathrm{~mm}$, width $4.4 \mathrm{~mm}$. Head rounded, clypeal margin rounded and truncated in the middle; frontoclypeal ridge not expressed, clypeo-genal sutures finely sulcate, eyes completely divided by canthus. Clypeus densely transversely rugulate-punctated. Vertex arcuately carinate (Figs 2-3).

Pronotum about 1.48 times as wide as long; densely punctured with elongated granules. The disc of pronotum with a wide depression in the middle; the surface along the sides of the depression smoothed, with sparse punctuation (1-3).

Elytra with small and round punctures in grooves; intervals slightly convex with 2-4 rows of small granules with bristles. The 7 th stria distinctly curved near its base.

How to cite this article: Zinchenko V.K. 2018. New and poorly-known species of the subgenus Parascatonomus Paulian, 1932 (Scarabaeidae: Onthophagus) from Vietnam // Russian Entomol. J. Vol.27. No.4. P.367-369. doi: 10.15298/rusentj.27.4.03 


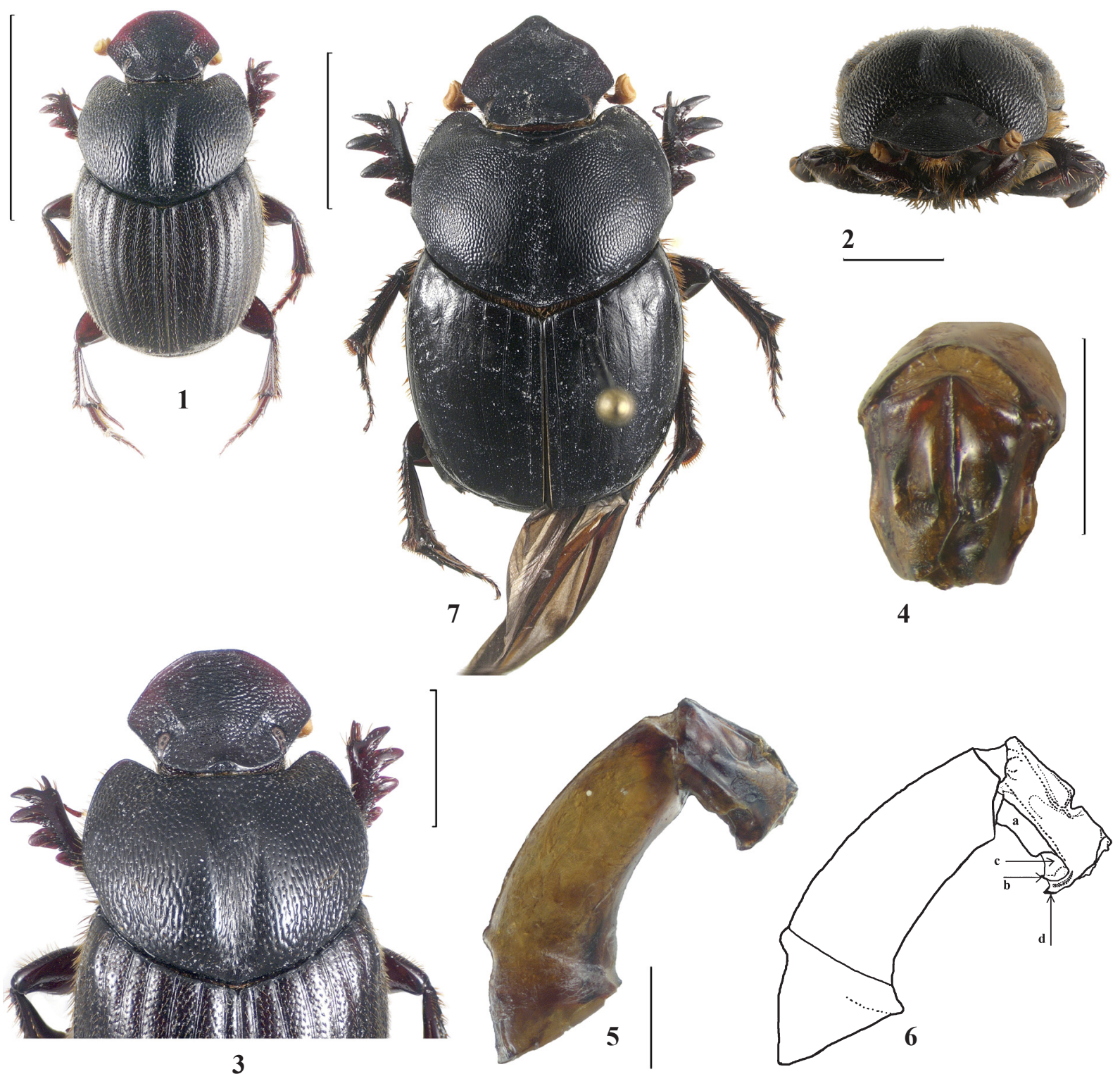

Figs 1-7. Onthophagus (Parascatonomus) spp: 1-6-O. abramovi sp.n., holotype, O’; 7 - O. rhombocephalus Kabakov, 1992, ㅇ; 1-2, 7 - habitus; 3 - head and pronotum; 4- 6- aedeagus; $1,3,7$ - dorsal view; 2,4 - frontal view; $5-6$ - lateral view. Scale bars $5.0 \mathrm{~mm}$ $(1,7) ; 2.0 \mathrm{~mm}(2-3) ; 0.5 \mathrm{~mm}(4-6)$. Parts of parameres: a — baso-lateral plate; $\mathrm{b}$ - apico-lateral tooth; $\mathrm{c}$ - medio-lateral notch; $\mathrm{d}$ - apical tooth.

Рис. 1-7. Onthophagus (Parascatonomus) spp: 1-6-O. abramovi sp.n., голотип, О7; 7 - O. rhombocephalus Kabakov, 1992, 우 1-2, 7 - общий вид; 3 - голова и переднеспинка; 4- 6 - эдеагус; 1, 3, 7 - сверху; 2, 4 - спереди; 5-6 - сбоку. Масштаб 5,0 тш (1, 7); 2,0 mm (2-3); 0,5 mm (4-6). Части парамер: a - базально-боковая пластина; b - вершинно-боковой зубец; с - средне-боковая выемка; d - вершинный зубец.

Metasternal shield and sternites of the abdomen in the middle covered with short hairs, along their sides with long yellow hairs. Metasternum anteriorly raised, canoe-shaped. Pygidium feebly convex, ridged at its base, micro-shagreened, scattered with oval punctures, each with a thin hair.

Legs rather thick; protibii with four external teeth; the ratio of the lengths of metatibium spurs and metatarsomers: $1.07 ; 1.0,0.47,0.25,0.18,0.3$.

Aedeagus (Figs 4-6) of medium size. Phallobase elongate, about $1.75 \mathrm{~mm}$ long (in lateral view) and $0.7 \mathrm{~mm}$ wide at its apex (in dorsal view). Parameres relatively large, subquadrate in dorsal view, about $0.8 \mathrm{~mm}$ long (in lateral view on the right), each baso-lateral plate somewhat elongate, medio- lateral notch preapicalle excavated. Apico-lateral tooth very small, apical tooth large (Fig. 6b, d).

Female unknown.

DIAGNOSIS. From the described Indo-Chinese Parascatonomus species having the rounded clypeus, the densely punctured pronotum and no metallic luster in the body coloration, the new species can be distinguished by the following characters: compared to $O$. (P.) anguicorius Boucomont, 1914 and $O$. (P.) mairuu Masumoto, 1989, by the absence of a tubercle on the front incline of pronotum; compared to $O$. (P.) aerumnosus Balthasar, 1963, O. (P.) kuantunensis Balthasar, 1942, O. (P.) chiangraiensis Masumoto, Ochi et Hanboonsong, 2007, by the absence of punctuation in front 
corners of the pronotum; compared to $O$. (P.) chapaensis Kabakov, 1992 two thirds of the pronotum sides densely punctured. The pronotum of the new species is covered with large and elongated granules, a deep longitudinal depression on the disk. Besides, the frontoclypeal ridge of all the aforementioned related species looks like a transverse spindle, whereas it is as a small tubercle in the new species. The male genitalia of the new species differ from those of all the aforementioned species in having the excavated medio-lateral notch and large apical tooth.

ETYMOLOGY. The species is named in honor of the well-known Russian zoologist, Dr Alexei V. Abramov (St. Petersburg, Russia), who collected the holotype.

NOTE. The beetle was collected by pitfall traps from under the canopy of disturbed forest.

\section{Onthophagus (Parascatonomus) rhombocephalus Kabakov, 1992 \\ Fig. 7.}

MATERIAL. 9 , Vietnam, Kon Tum Prov., / Kon Plong District, $14 \mathrm{~km} \mathrm{~N} /$ of Kon Plong Town, h $1030 \mathrm{~m} / 14^{\circ} 43^{\prime} 20^{\prime \prime}, 108^{\circ} 18^{\prime} 58^{\prime \prime} \mathrm{E}$ / 9-23.04.2015 / A.V. Abramov leg.

DESCRIPTION. Male. Figures of the head and genitalia see Kabakov [1992].

Female. Body black. Antennal clubs yellowish, mouth parts tinged with red. Total body length $16 \mathrm{~mm}$, width $6 \mathrm{~mm}$. Body top hairless, but propleures, epimeres of mesonotum, front margin of metanotum and sternite sides with bunches of reddish hairs.

Head almost diamond-shaped, clypeus triangle, with an apical process bent upwards. Eyes completely divided by canthus. Head surface in coarse transverse wrinkles. Frontoclypeal ridge thin, reaching clypeo-genal sutures. Vertex smooth, as a triangle projection with a sharpened tooth at its top. Pronotum heart-shaped, its anterior angles widely rounded, its base fringed in the middle, and it surface granulated.

Elytra with thin, double grooves; intervals flat, shagreen, with small irregular dots. Pygidium ridget at base, heavily shargreened and with dense oval punctures.

Metasternal shield with a conical process, covered with rasp-like punctures and long reddish hairs. Apical spur of fore tibia sharp and bent ventrad. Middle and rear-femora with numerous small punctures bearing short yellow hairs.
REMARKS. Until now, this species has been known only from the holotype male collected from the Province of Gia Lai, Vietnam. The new locality lies north of the neighbouring Province of Kon Tum. By general appearance, the newly discovered female does not differ from the male (see Kabakov, 1992).

NOTE. The beetle was collected by pitfall traps from under the canopy of disturbed forest.

ACKNOWLEDGEMENTS. The author is grateful to A.V. Abramov (St. Petersburg, Russia) for the material provided for this study and to D.V. Logunov (Manchester, UK) for editing the English of the first draft. The author also wishes to thank S. Tarasov (Blacksburg, USA) for useful critical comments and the help with literature. The study was supported by the Federal Fundamental Scientific Research Programme for 2013-2020 (AAAA-A16-1161214101.- № VI.51.1.9.). Material used in the study was provided by the Institute of Systematics and Ecology of Animals Siberian Branch of RAS, collection "Siberian Zoological Museum", developed within project (AAAA-A17-117101070002-6).

\section{References}

Kabakov O.N. 1992. [Taxanomic status of Parascatonomus (Onthophagini, Scarabaeidae), with the description of new species from Southeast Asia] // Systematika i ekologiya nasekomykh Vietnama. Moskow: Nauka. P.196-209 [in Russian].

Kabakov O.N., Napolov A. 1999. Fauna and ecology of Lammelicornia of subfamily Scarabaeinae (Coleoptera, Scarabaeidae) of Vietnam and some parts of adjacent countries: South China, Laos and Thailand // Latvijas entomologs. No.37. P.58-96.

Krikken H., Huijbregts J. 2008. Distinguishing the Sundaland species in the Onthophagus (Parascatonomus) aurifex group (Coleoptera, Scarabaeidae: Scarabaeinae) // Tijdschrift voor Entomologie. Vol.151. P.173-185.

Masumoto K., Ochi T. 2014. Relatives of Parascatonomus (Coleoptera, Scarabaeidae, Onthophagini) from North and Northeast Thailand // Kogane. No.16, P.61-78.

Tarasov S.I., Kabakov O.N. 2010. Two new species of Onthophagus from Indochina, with a discussion of some problems with the classification of Serrophorus and similar subgenera // Zootaxa. Vol.2344. P.17-28.

Tarasov S.I., Solodovnikov A.Y. 2011. Phylogenetic analyses reveal reliable morphological markers to classify mega-diversity in Onthophagini dung beetles // Cladistics. Vol.27. P.1-39. 